\title{
The idea of
}

\section{citizenship in the Latin American debate}

\section{Carlos Sojo}

Director, Costa Rica Office

Latin American Faculty

of Social Sciences

csojo@flacso.or.cr
This article looks at some of the most significant contributions to the contemporary Latin American debate on citizenship. The subject has taken on central importance in the justification of public policy throughout the continent, chiefly because it allows the approach taken to the social question to be based on active integration of economic, social and cultural phenomena, and makes it possible to address aspects of life in society - such as gender, ethnic and environmental conflicts- that pose major challenges for political regimes and for economic stability. Following an introductory section, the article reviews the conceptual underpinnings of sociological thinking about citizenship, examines the implications of globalization for the analysis and identification of problems associated with citizenship, summarizes some Latin American contributions that have helped to expand the explanatory capabilities and practical usefulness of the concept and, lastly, offers some final considerations. 


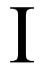

\section{Introduction}

Sociological re-evaluation of the issue of citizenship was given a new impetus by the awakening of Europe from the authoritarian rigours of the Second World War. This historical point is important because it seems clear, as Escalante (1995) notes, that thinking about citizenship tends to take place cyclically, often in the wake of political traumas. In Latin America, the renewal of debate about the subject coincided with the democratic transition that began to take hold right across the region in the mid-1980s. Consequently, the first thing that can be said is that the issue of citizenship is closely linked to the more general one of democratic government. Once the terms of the pro-democracy political pact have been established, societies begin to debate the particular characteristics of this relationship between the individual and authority, between private interests and collective needs, between "ourselves" and "the others".

At the formal legal level, the question of citizenship is resolved by creating a prescriptive framework of rights and duties binding on all individuals included in a historico-territorial community, or what is called a nation. The rights pertaining to citizenship are thus expounded in the constitutional charter, which at the same time defines who citizens are and who benefits from and is bound by these rights and duties.

At the politico-ideological level, citizenship is reflected as the dominant self-awareness that is held to enshrine the integrative substance of society, often in an affirmation that does not admit of empirical confirmation. Thus, as Tenorio (1995) puts it, reviewing the exclusionary underpinnings of gestatory civic culture in the United States, "citizens are those who are citizens, who act in a citizen-like manner". Citizenship is an affirmation of community, largely based on the idea of the "other". A person is a citizen in relation to those who are not. In the cold war world, ideological divisions made it easier to identify the citizenship of communities that in many cases were subject to authoritarian political regimes: socialists against imperialism, capitalists against communism. At present, this idea of citizenship seems to correspond to the formal idea of "nationality", because it is the common denominator that identifies the citizen community thus defined as a "nation". Nonetheless, there are still some politico-ideological considerations that go beyond this: religious denominations, to take the most dramatic example, tend to create communities that transcend national States. Ethnic differences, by contrast, yield before the affirmation of a dominant culture that is held to be the interpreter and guarantor of citizenship.

Sociological thinking is grounded more in the dynamic of social integration, or the identification of forms of exclusion within community environments that seem to be formally homogeneous. As Jelin (1993, p. 25) puts it, what this is about is not the ahistorical affirmation of a set of practices that define citizenship, but rather a sphere of relationships pertaining to "a conflictive practice linked to power, which reflects struggles over who can say what, by determining what the shared problems are and how they are to be addressed".

In what follows, we review some aspects of the conceptual discussion about citizenship and their implications for the political debate in Latin America. We first analyse the classical formulation of the concept in post-war British sociology. We then consider what the implications of globalization are for an idea that is strongly rooted in the specificity of the nation State, a locus that is in crisis in the age of transnationalization. Lastly, we touch on some contributions that have come out of Latin America's experience in the 1990s. 


\section{II}

\section{Marshall and the classical idea of citizenship}

The modern conception of citizenship originates in the thinking of the British sociologist Thomas H. Marshall, set forth for the first time in a series of conferences held at the University of Cambridge in 1949 and published the following year under the rather misleading title Citizenship and Social Class. I say "misleading" because this author was not really trying to analyse the differential opportunities for understanding the problems of citizenship using a theory of social classes, noting rather that in a way the "logic" he was working from was a different one. Marshall believed that social classes could be understood on the basis of two analytical procedures: an approach, undoubtedly Weberian in origin, whereby class is seen as being based on a "hierarchy of status" sustained by law and custom, and a typology of social classes originating in the results of the linkage between the institutions of property and education and the workings of the production structure. In both these cases, the first of them referring to the stratification that predated capitalism and the second to more modern forms deriving from industrialization, the principles underlying citizenship and class are opposed. "Citizenship is a status bestowed on those who are full members of a community. All who possess the status are equal with respect to rights and duties... Social class, on the other hand, is a system of inequality. And it too, like citizenship, can be based on a set of ideals, beliefs and values" (Marshall, 1992, p. 18). The argument that follows seeks to answer the central question of how two opposing and "warring" principles flourished in Britain during the three centuries prior to the mid-twentieth century. Although the study is very local and may be criticized for numerous omissions, particularly in the light of the global changes at the end of the century, Marshall's definition is still useful for those considering the scope for consolidating democracy in societies that are only just becoming acquainted with civilian government or in others that, while they may not have suffered the rigours of civil war, have experienced the ravages of economic crisis and the no less stringent measures taken to stabilize their economies and re-establish growth.

Marshall breaks down the idea of citizenship into three elements: civil, political and social. He has been much criticized for settling on an excessively sequential chronological development. But once it is recognized that these developments do not take place in isolation only after the end of the preceding stage but, as he himself pointed out, are obviously overlapping, and once it is accepted that there can be progress and indeed reverses with any one of these elements, Marshall's analytical approach can be reconstructed with fewer misgivings. For him, civil rights are composed of "the rights necessary for individual freedom": freedom of expression, thought and religion, the right to private property, freedom of contract, and the right to justice. Political rights are related to the right to participate in the exercise of public authority, as a member of a body invested with political authority or as an elector of the membership of these bodies. The expansion of social rights, lastly, and the greater flexibility in their design necessitated by the variety of problems they may encounter, mean that they may range "from the right to a modicum of economic welfare and security to the right to share to the full in the social heritage and to live the life of a civilised being according to the standards prevailing in the society" (Marshall, 1992, p. 8).

One's first reaction is that while it does not seem too difficult to affirm and even identify civil and political rights, the third definition is extraordinarily broad. Consequently, it has to be recalled that Marshall is concerned to identify the institutional forms corresponding to the development of each of these rights. Indeed, it is to this that he devotes the rest of the work.

Thus, the institutions that guarantee and mould civil rights are courts of justice, and the attainment of civil citizenship rights has a great deal to do with the consolidation of procedures for administering justice and protection that are economically accessible to all. Individuals are the primary beneficiaries of these rights. In the eighteenth century, the courts played a crucial role in defending individual freedom, even against the public authorities. In the economic field, freedom of labour -what Marshall calls "the right to follow the occupation of one's choice in the place of one's choice, subject only to legitimate demands for preliminary technical training" (Marshall, 1992, p. 10)- was 
essential to the development of industrial capitalism, as Marx recognized in the mid-nineteenth century. By the beginning of that century, individual economic freedom was regarded as axiomatic.

It is then, Marshall thinks, that it becomes possible for the formative period of political rights to begin. What this means is not expanding the civil equality already achieved by means of new rights, but extending it to larger and larger sections of the population. "In the eighteenth century," Marshall notes, "political rights were defective, not in content, but in distribution; defective, that is to say, by the standards of democratic citizenship." (Marshall, 1992, p. 12). Long tied to civil citizenship, political rights were the privilege of a powerful minority of wealthy white men. They were not so much a right as a "capacity" of certain holders of civil rights. In the twentieth century, political rights became completely independent, at least for men, because the financial restrictions on who could vote and be elected began to be abolished and the trend was clearly towards universal adult male suffrage. Institutionally rooted in parliaments and local councils, political rights are primarily collective.

The origin of social rights goes back to the midnineteenth century, with policies to protect the poor and regulate incomes, but with a peculiarity similar to that seen in the case of the first political rights. Social benefits were granted in the form of assistance to people who were not citizens. In other words, the social assistance that was the forerunner of social citizenship rights had its origins in a form of relief that denied citizenship: "The stigma which clung to poor relief expressed the deep feelings of a people who understood that those who accepted relief must cross the road that separated the community of citizens from the outcast company of the destitute" (Marshall, 1992, p. 15).

In today's Latin America this "exclusionary" application of social rights has found some new expressions, albeit certainly not institutional ones of the type Marshall was questioning. We shall be looking at this later on.

Marshall recognized that, in his time, the application and expansion of rights arising in this way had not yet contributed to a substantial reduction in inequality. The response that he ventures is closely linked to his assessment of how social rights had developed in the twentieth century. The social struggles of that century led to a profound change in the aspiration to social citizenship, the starting point being efforts to combat social deprivation by "raising" the floor of the building but leaving its structure intact. This was succeeded by the aim of transforming the structure of the system, turning -in Marshall's words- "a skyscraper into a bungalow". This change, however, came up against "natural limits", prominent among them being the procedures designed to combine social integration efforts with the system of market pricing. Marshall concludes that extending social services is not necessarily a way of levelling incomes, but rather an instrument for "enriching the material substance of civilised life". In other words, the purpose of social security systems is not to do away with income differentials, as in the case of the abolition of social classes thus defined, but to do away with the differences in social status that might arise from income inequalities, among other things. Another limit is the availability of resources for satisfying individuals' growing expectations. Marshall recognizes that the "target is perpetually moving forward, and the state may never be able to get quite within range of it. It follows that individual rights must be subordinated to national plans" (Marshall, 1992, p. 35). This limitation is conditioned by the different strength of the competing demands, and does not mean that individual rights are defenceless: they can be defended in the appropriate legal setting, while collective interests originate and are aired in parliament and local government.

The argument moves on, lastly, to the affirmation of two paradoxes that illustrate how the principle of individual gain, which is the engine of the market economy, has been able to survive and develop strongly alongside a principle as contradictory as equality, which is sustained by the ideal of citizenship. In a paragraph as lucid as it is lyrical, Marshall says that:

"Social rights in their modern form imply an invasion of contract by status, the subordination of market price to social justice, the replacement of the free bargain by the declaration of rights. But are these principles quite foreign to the practice of the market today, or are they there already, entrenched within the contract system itself? I think it is clear that they are" (Marshall, 1992, p. 40).

The solution to this paradox lies in the fact that the institution of citizenship offers individuals rights but also imposes responsibilities, which become not a duty to submit to the absolute will of the State, but a permanent incitement to act in a way that furthers the welfare of the community.

The other paradox derives from the relationship between citizens and contracting parties in the market economy. Personal gain is the force that governs the 
liberal system of contracts, whereas public responsibility is the engine of social rights. In Marshall's thinking, the idea of citizenship draws on both principles. He suggests that the citizen is asked "to answer the call of duty", while at the same time room is left for motives of individual self-interest.

In summary, it seems to me that the way citizenship rights have developed from their civil origins into social rights is the result of an encounter between the individualistic ideals driving capitalism and many of the egalitarian values driving the creation of the democratic political system. This encounter, which
Wolfe (1977) attributed to liberalism and democracy, Marshall sees as the positive forward movement of two opposing principles that work in harmony because they are mutually limiting. As Bryan Roberts puts it in an unpublished essay, Marshall defined citizenship as a principle of equality that coexists uneasily with the social inequality resulting from the play of market forces. He tends to see citizenship as being fully developed when the tensions of market-induced social inequality are mitigated by the stimulus of equal opportunities and social mobility (Roberts, ed., 1998, p. 3).

\section{III}

\section{Citizenship and globalization}

The main challenge in applying Marshall's thinking today, I believe, is to adapt its tenets to the changing conditions of the capitalist world in the post-cold war era. Its relevance is undeniable because, as Robert Moore suggests in his prologue to the work of Marshall's being discussed here, the idea of citizenship has emerged in the post-cold war world not as an expression of the liberalism that might have been its source in its mid-twentieth century version, but as a manifestation of resistance to a presumedly global and presumptuously universal liberalism which does not recognize the legitimacy of State intervention to regulate relationships between individuals and the market. In a way, this is the best legacy of the Marshallian idea of citizenship. There is no citizenship in an unalloyed market; consumers are not citizens because they have no rights. Their only duty is to realize individual gain.

In an essay to complement Marshall's study that his London School of Economics colleague Tom Bottomore wrote 40 years later, there is a thoughtprovoking review of the implications that the most significant global changes of recent years may have for Marshallian thinking about citizenship (Bottomore, 1992).

Global developments mean that a distinction needs to be drawn before consideration can be given to the three areas of citizen rights defined by Marshall. Bottomore follows up the suggestion made by other authors that a distinction should be made between formal citizenship, defined as membership of a nation
State, and substantive citizenship, which implies the possession of rights and the ability to exercise them, with some degree of participation in the public and private spheres, within the three areas defined by Marshall. Brubaker (cited by Bottomore, 1992) notes that formal citizenship is not a prerequisite for any kind of substantive citizenship, being neither a sufficient nor a necessary condition. It is not a sufficient condition because, as women and subordinated ethnic groups know very well, it is possible to belong to a national community while at the same time being excluded from the enjoyment of certain rights that are monopolized by others. It is not a necessary condition because it is possible to enjoy certain social, civil and even political rights without actually being part of a national community.

This contribution is very important because it means that the debate about citizenship can be removed from the conventional legal framework and placed on a strictly sociological level. According to Bottomore, the formal aspect of citizenship has been called into question because of the spread of three phenomena. Firstly, the growth of migration not only from peripheral countries to the developed powers, but among developing areas within the peripheries themselves, which has led to growing demands, for social rights in particular, that States cannot simply ignore even when those making them are not formally citizens. Secondly, a tendency towards the internationalization of legal working which necessitates favourable conditions for the movement and legal residence of foreigners. And 
thirdly, the more general problem of the relationship between residence and citizenship, and the definition of "the nation" as the exclusive locus of citizenship.

Substantive citizen rights do not arise in a cumulatively and mechanically consequent way as Marshall might be thought to assert, at least on a hasty reading. The transformation of the socialist countries made it plain that social rights could be developed quite freely in situations where there was far-reaching repression of political and civil rights. Again, democratic reform opened the way to a rapid recovery of civil liberties and political rights in those countries, and at the same time to a gradual erosion of the achievements of social equality in the Marshallian sense, i.e., over and above incomes. Meanwhile, although a good deal of information is available about shortcomings in the attainment of objectives associated with social rights, there are gaps when it comes to civil liberties and political rights, and new areas of difficulty have emerged. The issue of intellectual property, it seems to me, is a good example of a field in which globalization is beginning to create serious conflict between individual interests and collective benefits. The intellectual property protection agreements adopted under the auspices of the World Trade Organization (WTO) have served to create global rights over knowledge and its distribution and commercial use. The leading holders of these rights are no longer individuals rooted in particular nations but corporations that act on the global stage. ${ }^{1}$ Purely by way of example, it is well known, and has been the subject of international criticism, that the traditional knowledge of native peoples concerning the curative uses of certain animal and vegetable species has ended up as the intellectual property of pharmaceutical multinationals. As Shiva (2000) points out:

"The competition is highly unequal not only because the corporations are powerful and the poor are not, but because the rules of free trade allow corporations to use the machinery of the nationstate to appropriate resources from the people, and prevent people from asserting and exercising their rights."

\footnotetext{
${ }^{1}$ The Agreement on Trade Related Intellectual Property Rights (TRIPS) was conceived and shaped by three organizations: the Intellectual Property Committee, comprising 12 United States corporations; the Japanese Federation of Economic Organizations (Keidanren) and the Union of Industrial and Employers' Confederations of Europe (UNICE) (Shiva, 2000).
}

The issue of sustainable development, meanwhile, opens up a sphere in which the limits of individual freedom, the importance of the national and even the primacy of "the human" or "the social" as development factors are unclear. Van Steenbergen (1994) points out how little progress has been made in analysing the linkage between the issue of citizenship and "the environmental or ecological "problématique". He suggests that this subject can be approached in three ways. Firstly, by confronting the anthropocentric view of rights and expanding it to include the rights of animals or even those of unborn human beings, a particularly sensitive element in the "pro-life" struggle of anti-abortion organizations. Secondly, in the environmental approach to citizenship, by stressing people's "responsibility" to defend the natural world: this confrontation with "the primacy of society over nature" (ibid., p. 146) is unquestionably a key aspect in the North-South dialogue concerning development opportunities, as it implies a sort of penalization of social uses for territory and a diminution of the sovereignty of national States over natural resources. And thirdly, by seeing global ecological citizenship as the outcome of a comprehensive understanding of planetary resources, combining options based on the control and safeguarding of resources. The idea of control is related to the development of the technical, political and institutional tools needed to deal with the tasks of sustainable development. The idea of safeguarding, by contrast, involves looking at the earth as a habitat, an indissoluble relationship based on equality of rights for all living creatures.

The same is true of the known weaknesses of the democratic process, brilliantly set forth by Bobbio (1984) in his well-known work The Future of Democracy (Il futuro della democrazia). The limitations on the accreditation of individuals able to vote, the exclusion of sections of the population from the right to represent collective interests in the public sphere, the growing homogeneity of political offerings, which reduces the real scope for choosing among alternatives, and the curtailing of the sphere in which decisions are submitted to the electoral process; these are some of the limitations that daily thwart the full exercise of political citizenship rights, even if we follow Bobbio in understanding democracy in its narrowest sense as a decision-making procedure. It is in this sphere that the cultural issue has meant an ongoing redefinition of the diversity of situations to which globalization is exposing the traditional idea of citizenship. Habermas (1994, p. 25) frames it as an active view of citizenship whereby 
the organization of individuals does not give rise to a legal status vis-à-vis the State, a credential, since:

“...citizens are integrated into the political community like parts into a whole; that is, in such a manner that they can only form their personal and social identity in this horizon of shared traditions and intersubjectively recognized institutions".

The features of cultural integration that he refers to here are taking on renewed importance in the search to adapt the issue of rights to the social and political changes now going on. García Canclini's suggestion (1995, pp. 30 ff.) that the creation of post-modern identities is based on transterritoriality and multilingualism is thus an illuminating one.

"They are structured -these identities- less by the logic of States than by that of markets; rather than being based on oral and written communications covering personalized spaces and effected at close quarters, they operate through industrially produced and technologically conveyed culture and deferred, segmented consumption of goods."

These are integration patterns, then, that are well suited to this global stage where the relationship with the market also gives a sense of belonging and shapes a social community. Globalization thus has to be understood not only as a process whereby stock market and commercial transactions increase in scale and reach, or even -as Held and others (1999, p. 28) have notedas a shift in the centres of power taking them further away from the places experiencing their effects. What is proposed is the general adoption of an idea of consumption that goes beyond the logic of possessive individualism (McPherson, 1977) to the benefit of "collective appropriation, in relationships of solidarity with and consideration for others, of goods that provide biological and symbolic satisfactions" (García Canclini, 1995, p. 53).

Nonetheless, it may be thought that, where political and civil rights are concerned, globalization has manifested itself in a tendency towards uniformity, towards the definition of parameters that are universally acceptable over and above cultural or technical differences (as in the case of political systems). The same is not true of social rights, which are the most controversial, firstly because of the scope of the social policies to which they are now giving rise, and secondly because of the effects that even defining them must have on the social structure.

This appreciation gives rise to an argument which is crucial for an understanding of the phenomenon of citizenship, and which Marshall did not explore. The definition of rights is a field of social struggle, an arena of political confrontation and class struggle. As the Sussex professor emeritus puts it:

"It is evident today that what have been called the rights of citizenship, which I now refer to in a broader context as human rights, are in a continuous process of development which is profoundly affected by changing external conditions (especially in the economy), by the emergence of new problems and the search for new solutions. One major, more or less constant, factor in this process, as I have emphasised, has been the antithesis between the inegalitarian structure and consequences of a capitalist economy and the claims for greater equality made by diverse social movements since the end of the eighteenth century. Within this general opposition of different interests and values the conflict between classes and classbased parties still plays a leading role as a principal source of policies intended to limit or extend the scope of human rights, and in particular the degree of collective provision to meet what are defined as the basic needs of all members of a society at various stages in its development" (Bottomore, 1992, p. 89).

Bottomore then goes on to recognize, somewhat reluctantly, that in the late twentieth century certain antagonisms that are not associated with production (such as those between the sexes or among ethnic groups) took on a central importance, although he hastens to point out that many of them originate partly in inequalities generated by capitalism. As we shall see later on, these antagonisms - which certainly cannot be understood in isolation from the capitalist sphere, but which are not peculiar to it- are essential to an understanding of the contemporary Latin American debate about citizenship. The crux of this contribution of Bottomore's, to my way of thinking, is that it identifies the centrality of social action in defining what a society understands by and defends as citizenship rights in a particular historical situation. 


\section{IV}

\section{Latin America and citizenship}

We shall now review some contributions to the debate about citizenship in Latin America. The first thing to note is that the renewal of interest in the subject has much to do with the way political and academic sectors have become reconciled to a democratic form of political system. From being considered an expression of middle-class domination, a façade for class totalitarianism, democracy has become an unquestioned value. This does not mean, however, that there has been any relaxation of vigilance or willingness to overlook the failings of the recent democratization process in the region, particularly where social development is concerned. The search for ways of approaching this new relationship with democracy has led to the emergence of conceptual debates for which there was previously no place, and which have unquestionably enriched our knowledge of the region's political realities: the subject of governance, the issue of civil society and, more recently, thinking about comprehensive rights within the framework of the citizenship concept are all means towards this end. The subject of governance became important when the region's new democracies had to start dealing with the day-to-day problems of political management at a time when social demands were growing and the scope for a public-sector response was limited by the economic crisis and by stabilization and reform policies whose chief objective was to contain public spending. ${ }^{2}$ The issue of civil society has provided the framework for new debates about social matters, and these debates have taken on particular importance now that the region has left behind it many of the political-military confrontations that had subjected the relationship between State and society to all sorts of rigid structural determinations. The debate about civil society, while it is still largely focused on taxonomic aspects, has allowed for recognition of the diversity of the social processes and subjective positions around which the contemporary movement of society hinges. ${ }^{3}$

\footnotetext{
2 See Camou (2000) for a conceptual analysis of governance that is sensitive to the peculiarities of the problem in Latin America.

3 Biekart's analysis (1999) of the construction of civil society in post-war Central America summarizes the most salient features of
}

The idea of citizenship is a relevant one for dealing with the socio-political challenges of Latin America, in my opinion, for two key reasons. Firstly because it sets out from a precept of equality which accords with the aim of democratic modernization even if it comes up against the effects of economic reform and the contemporary organization of the production system. Secondly because, as Roberts (ed., 1998) points out, it allows an integrated approach to be taken to political, economic and social matters, which may be the only way of dealing with a future situation in which it seems that the growth of companies will always be given precedence over the welfare of individuals. It offers a possible understanding of democracy that is not confined to the powers of the State, on the one hand, or the creation of freedom and wealth in the marketplace, on the other. It is an opportunity to recognize the liberating power of rights. As Touraine (1994) puts it:

"The subject of citizenship means the free, voluntary construction of a social organization that combines the unity of the law with the diversity of interests and respect for fundamental rights. Instead of identifying society with the nation, as in the most important stages of American independence or the French Revolution, the idea of citizenship gives a solid meaning to that of democracy: the construction of a truly political space that is neither the State nor the market."

The return to citizenship thus seems to be an opportunity to place social issues back at the centre of the analysis when studying the performance of political and economic systems. This overarching objective can be discerned in the diversity of Latin American studies dealing with the issue. In particular, though, it must be recognized that the subject of citizenship has been little addressed from a general standpoint, as far more attention has been given to analysing the problems of specific citizenships, if it can be put this way. National studies dealing with the subject emphasize particular

the Latin American debate on the basis of what he sees as the primacy of the Gramscian approach emphasizing popular struggle against the hegemony of the market and the State. 
aspects, such as the ethnic or cultural issue or political and social problems, but it is not common to find analyses that weigh up the question of citizenship in all its many aspects in particular societies. This shortage -so far as we have been able to ascertain- of comprehensive studies into the three dimensions of citizenship may be a clear indication that the problems of citizenship in Latin America do not centre to any large degree on issues of geopolitics and national States, because the processes that generate these problems are also understood to be situated at a transnational level. It is therefore understandable that the studies we know of should be largely confined to aspects associated with particular failings, deficient citizenships or certain subjectivities (such as women, ethnic groups, young people in deprived urban areas, etc.). In these cases, even when specific analyses are being undertaken, the explanatory presence of processes transcending national boundaries is recognized. To put it another way, the common denominator is that the criteria being worked with are those of substantive citizenship and not formal citizenship.

The subject of citizenship has been incorporated, from different analytical points of view, into thinking about the political performance of the Latin American democracies, some of which are confronted with the disintegrative tendencies of a culture of globalization that exerts a centrifugal force on the formation of national identities. From other perspectives there has been analysis of the impact of shifting production patterns on the consolidation of less deficient forms of social integration, and very particular attention has been paid to the characteristics of experiences of exclusion and deficient citizenships, especially those related to the concern of gender studies with the evolution of forms of discrimination against women. Much of the regional debate about citizenship, in fact, has its origins in the contributions of Latin American feminist thinking to our understanding of the limitations on full participation by women in the exercise of the citizen rights to which they are entitled.

Citizenship as identity has been very thoroughly discussed, as we noted earlier, by García Canclini (1995) in his study of cultural policy and consumption. His argument sets out from the homogenization effect that globalization has on national identities, which represent a sense of sameness but, even more, an awareness of difference: "Citizenship and rights are not just about the formal structure of a society; they also indicate the state of the struggle for recognition of others as possessors of 'valid interests, relevant values and legitimate demands"” (ibid., p. 21). García Canclini's argument postulates that the status of consumer is increasingly what integrates national communities, and that with globalization this status becomes detached from links of origin and is redefined:

"A nation, for example, is no longer much defined by territorial limits or political history. Rather, it survives as an interpretative community of consumers whose traditional habits - the food they eat, the languages they speak-mean that they have a particular way of relating to the objects and information that move around international networks. At the same time, we find international communities of consumers -we have already mentioned young people and television viewersthat provide a sense of belonging when national loyalties are diluted" (ibid., pp. 49-50).

The author concludes his reflections by wondering about the implications of these new bases of identity for the formation of citizenships in what he terms "increasing participation through consumption". He is aware that the rationality of individual benefit that guides consumption is not necessarily favourable to ideas of solidarity and the common good. Nonetheless, he recognizes that many antagonisms that are central at the national level are played out and aired in wider ambits that are better informed about what is happening around them. He thus proposes the restoration of "political" action to turn consumers into citizens through redefinition of the social role of the market and social integration based on "cultural subsystems" that are not defined in the national socio-territoriality.

The crux of his position lies in the understanding of the prerequisites for the transition from consumers to citizens and not, as might be affirmed, in the replacement of consumers by a lofty, utopian citizenry that gives precedence to collective interests over individual ones. There are three prerequisites for a sound link between consumption and the exercise of citizenship: i) easy access to a very large, diversified supply of goods and messages that are representative of the markets for these; ii) product quality control based on adequate information and the ability to withstand advertising, and iii) "democratic participation by the main sections of civil society in decision-making in the material, symbolic, legal and political spheres where consumption is organized, from sanitary certification of foodstuffs to the awarding of radio and television frequencies..." (García Canclini, 1995, p. 53). 
I note in García Canclini's argument a commendable concern to identify mechanisms for constructing citizenship in an environment dominated by relationships of consumption (of goods, services and symbols) that have inflated the power of individualism and minimized the importance of national cohesion. Nonetheless, it may be said that factors apparently accounting for a widespread cultural situation may develop with different nuances in different dimensions. For example, it is obvious that communication flows, and thus the information available to guide citizens in their consumption, are much greater in urban areas than in rural ones, and although it is true that the region is urbanizing rapidly, some countries, such as those of Central America, are still predominantly rural. The creation of a culture of informal life, which results from the extension of non-mercantile networks of interchange and production, is placing a larger and larger proportion of the population in Latin America's cities outside the rationality of a consumption that, viewed from the logic of capital, only serves individual interests. The rigidity of labour markets has fostered the development of forms of social capital that do not relate production and consumption practices to individual gain and the ideal of competition, but rather to cooperative practices and solidarity networks, which create collective benefits far more than individual gain (Pérez Sáinz, 1996). It is a matter not so much of participation in alternative transnational flows as of a local strategy for the formation of social identities that allows for incorporation into the dominant networks of transnational culture.

Calderón, Hopenhayn and Ottone (1996) bring to the debate a proposal for extended citizenship that seeks to identify functional links between the requirements of economic development and the needs of social integration. Their contribution also addresses an issue that is central in defining the new outlines of a substantive citizenship consisting in the construction of identities based on a non-antagonistic understanding of otherness. Extended citizenship is no longer constructed through the affirmation of an identity that is contrary to "the others", but rather through an identity characterized by solidarity and cooperation. In their proposal, the idea of citizenship takes on "semantic complexity" and helps to extend the idea of social and political integration in three ways. These are, first and foremost, "greater productive equity", which refers to the scope for achieving participation in the dynamic components of economic growth and thereby changing access to the enjoyment of goods and services.
Secondly, "greater symbolic equity", which they, like García Canclini, understand as wider opportunities to obtain and handle information, and to participate in cultural consumption networks; this symbolic equity is crucial for the formation of diagnostic capabilities in relation to the citizenship deficit, for the formation of rights and for the enforcement of standards, and is indissolubly linked to the transformation of public spaces in the direction of good government: more transparency, more information and greater powers for the governed to hold those who govern them to account. The third and last element identified by the authors is greater equity in the exercise of rights in a context where the existence of other identities is recognized.

Calderón, Hopenhayn and Ottone (1996) recognize that progress with the social integration processes referred to at the extended citizenship level does not happen in a neat, sequential way. On the contrary, they note that there is a tendency towards an expansion of equity on the symbolic plane that is improving citizens' ability to scrutinize public administration. But this process of creating and increasing expectations is not matched by a tendency for productive inequity to decline. This same paradox can be identified when, in Marshall's terminology, progress with civil and political citizenship rights creates an awareness of the limitations of social citizenship. As these authors put it:

"In the coming years, the asynchrony between slower movement in the processes of socioeconomic integration (driven by productive transformation and social rationalization) and more rapid integration at the symbolic and cultural level (driven by democratic political liberalization and the cultural industry) may become a core issue in the struggle for citizenship in many of the region's societies" (ibid., 1996, p. 78).

It is clear that a review of the issue of citizenship today needs to incorporate the effects of more advanced information and communication flows that give individuals greater opportunities to recognize and select policy or consumption options than they had in the past, when information and knowledge were subject to authoritarian centralization. Furthermore, a renewed sociological analysis of citizenship has to deal with a macrosocial and macropolitical environment that is undergoing profound changes, owing to the spread of democratic government in combination with an economic reform programme that is repositioning economies, the structural situations of individuals and the role of the State in relation to economic growth and 
development. It is recognized that, where Latin America is concerned, these new factors are crucial for the restoration of the idea of citizenship.

Lying between these concerns and the experience of real life is a range of thinking about citizenship whose starting point is, firstly, the need for a "bottom up" semantic reconstruction and, secondly, criticism of curtailed rights and deficient citizenships.

Addressing the "bottom up construction" of citizenship, Jelin (1993) offers an interpretation of the concept that is rooted in two basic considerations: the social construction of rights and the "revolutionary" nature of these, insofar as they generate collectively understood responsibilities. Jelin notes that the essential right is "the right to have rights", which she takes from Arendt's position (1973). Further on, she maintains that this is indispensable if there is to be recognition of the plasticity of rights and the potential for application of an incrementalist logic.

In Latin America, the dynamic of the social construction of rights and duties has the peculiarity that its setting is the experience of democratic transition and that it is accompanied by sociocultural practices designed to preserve elements of collective identification in a politico-authoritarian environment. Consequently, the citizenship construction challenge seems to be associated, on one side, with State responsibility for the consolidation of democratic institutions and, on the side of society, with the gestation of new practices and the adaptation of old ones, whether rooted in authoritarianism or solidarity, to make them consistent with democratic ideals and their institutional aspects.

"Where the formation of subjects is concerned, the issue is the learning of reciprocal expectations in relations with others. What are my rights? What are my responsibilities? This involves a twofold process in which I simultaneously recognize what responsibilities the other has towards me (and what my rights are) and learn what my responsibilities towards the other are. And in addition to this learning of expectations and responsible behaviour, it also entails the ability to define the extent of each subject's responsibility" (Jelin, 1993, p. 34).

This process of identifying rights by clarifying one's own and others' responsibilities is central in the feminist reconstruction of the issue of citizenship which, as we have already noted, has provided the basis for most theoretical and empirical explorations of this concept in contemporary Latin America. ${ }^{4}$ Bareiro and Clough (1996, p. 29) maintain that the feminist approach to the question of citizenship has centred on two considerations: firstly, the design of strategies to enable women to participate in public life with full recognition of their traditional and specific rights (such as those related to sexuality, work and violence) and, secondly, an inquiry into the logics of the conquest of rights, of subjective formation (which involves reassessing the political agenda), of citizen participation, and of the subject of power.

These authors set out to review the origin of the concept of full citizenship as a contribution to the Latin American feminist aspiration of attaining it. On the basis of a position that they trace back to Talcott Parsons, they emphasize the importance of identifying the mechanisms that govern the process of bringing excluded groups into full possession of citizenship. This may occur through assimilation or inclusion. According to Bareiro and Clough, assimilation entails the homogenization of the group and, consequently, incorporation occurs once the excluded have taken on the characteristics of the included. Inclusion, by contrast, accepts the differences of members, who are integrated in all their diversity. Although the authors acknowledge the usefulness of this distinction between forms of social integration for the debate on difference, which is central to feminist political culture, they do not elaborate on it. Nonetheless, it is obvious that the respective consequences of the two mechanisms described are very different.

Let us consider some contemporary processes in this light. Social compensation measures, for example, tend towards income equalization, but do not include action to remove other inequalities that prevent women and men from exercising citizenship fully. Acceptance of diversity in the civil and political orders of citizenship, as may be seen in the incorporation of indigenous peoples into the political systems of election and government, does not include acceptance as regards their social rights. Or, as happens with women in the political sphere, acceptance of diversity where suffrage is concerned does not necessarily mean that the same inclusive intent exists as regards their right to participate in decision-making and in power structures.

\footnotetext{
${ }^{4}$ For a sample of thinking about the subject of women and citizenship, see the compilation of papers presented at the "Mujeres, Participación Política y Ciudadanía" workshop organized by the Maestría Regional en Estudios de la Mujer (1997) of the University of Costa Rica. For the particular issue of the exclusion of political rights, see García Prince (1997).
} 


\section{Final considerations}

Viewing politics in terms of citizenship, originally an aspiration of liberal analysts, is now, particularly in Latin America, a political demand in its own right. This means that citizenship is not so much an established practice as a social aspiration in a region where there are severe constraints on the full exercise of it, most acutely for women and ethnic minorities, but also for the population at large. It is not just social rights that are deficient, but it is clear that the formation of collective responsibilities for the construction of nonexclusionary social systems is an indispensable prerequisite for the consolidation of democracy. In other words, democratic development without social rights is possible but unsustainable.

The shortcomings of other kinds of citizen rights are glaring in political systems that are increasingly monochromatic and closed to public scrutiny. Freedom of enterprise or economic liberty, which is at the heart of civil rights in the social environment of capitalism, continues to be reserved to an elite. One of the most salient features of our times is that while the reorganization of production necessitated by globalization may perhaps not be generating greater absolute exclusion, since extreme poverty at least is showing no general tendency to rise, there is more and more evidence of its capacity to create inequality, and this results in situations of exclusion. The model citizens of globalization are "hyper-citizens" who do not subscribe to State-accredited national identities and whose element is the transnational flow of trade, information and capital. The remainder are left in a "pre-citizen" state in which identity is the product of common deprivation and of limited participation in the most elementary benefits of citizenship: the civil right to freedom of employment is no longer available to sections of the population who are permanently unemployed or are self-employed in subsistence activities; politically, they are invisible as subjects because they do not appear on election or candidate rolls; and socially, they are faced with the fact that, now as formerly, there is clearly no inevitable relationship between economic growth and social welfare. In the final analysis, however, what "hyper-citizenship" and "pre-citizenship" have in common is that they are cut off from public life, when this is synonymous with the life of the national State. The former is cut off because the accumulation flows of material and symbolic goods no longer pass that way, and the latter because what little still does depend on national volition is not beneficial to it.

The reconstruction of citizenship, therefore, requires social integration on a number of levels. It must be national and transnational, because there can be no hope of consolidating identities of isolation. The blurring of nationalisms, as the disarray of Eastern Europe shows, is a manifestation of the authoritarian imposition of formal citizenship. New identities have to involve the recognition of oneself and of the "others" in and outside of the national space. The new reconstruction also has to take place on both a socioeconomic and a political level: the rights to well-being cannot be divorced from freedom, and this cannot exist in a context of deprivation and desperate struggle for day-to-day survival. Full citizenship for men and women is indivisible, although it still makes sense to study individual shortcomings separately.

Lastly, any attempt to reconstruct the ideals of citizenship has to set out from recognition of its semantic heterogeneity and its connotation as a social construct. In other words, the struggle for citizenship means daily, unremitting action, conflict and social antagonism. Full citizenship is the utopia, and of course no-one has yet found More's island of dreams. 


\section{Bibliography}

Arendt, H. (1973): The Origins of Totalitarianism, New York, Harcourt, Brace \& World.

Bareiro, L. and J. Clough Riquelme (1996): Nuevas voceras de la ciudadanía plena. Draft for the debates of the PMGL plenary session of the International Union of Local Authorities (IULA)/ Latin American Centre for Local Government Training and Development (Celcadel), Cochabamba, Bolivia, 14 to 16 November 1996.

Biekart, K. (1999): The Politics of Civil Society Building, Utrecht, The Netherlands, International Books.

Bobbio, N. (1984): Il futuro della democrazia, Turin, Einaudi.

Bottomore, T. (1992): Citizenship and Social Class, Forty Years On, in T.H. Marshall and T. Bottomore, Citizenship and Social Class, London, Pluto Press.

Calderón, F., M. Hopenhayn and E. Ottone (1996): Esa esquiva modernidad, in Desarrollo, ciudadanía y cultura en América Latina y el Caribe, Caracas, United Nations Educational, Scientific and Cultural Organization (UNESCO)/Nueva Sociedad.

Camou, A. (2000): La múltiple (in)gobernabilidad: elementos para un análisis conceptual, in Revista mexicana de sociología, year LXII, No. 4, Mexico City, National Autonomous University of Mexico (UNAM), UNAM Institute of Social Research.

Escalante Gonzalbo, F. (1995): El problema de la ciudadanía. Moralidad, orden y política, in Estudios sociológicos, vol. XIII, No. 39, Mexico City, El Colegio de México.

García Canclini, N. (1995): Consumidores y ciudadanos. Conflictos multiculturales de la globalización, Mexico City, Grijalbo.

García Prince, E. (1997): Derechos políticos y ciudadanía de las mujeres. Una vía género sensitiva y paritaria al poder y el liderazgo, San José, Costa Rica, Ministry of Culture, Youth and Sports, National Centre for the Development of Women and the Family.

Habermas, J. (1994): Citizenship and national identity, in B. van Steenbergen (ed.), The Condition of Citizenship, London, Sage Publications, Ltd.

Held, D. and others (1999): Global Transformations. Politics, Economics and Culture, Cambridge, Polity Press.
Jelin, E. (1993): ¿Cómo construir ciudadanía? Una visión desde abajo, European Review of Latin American and Caribbean Studies, No. 55, Amsterdam, The Netherlands, Centre for Latin American Research and Documentation.

Maestría Regional en Estudios de la Mujer (1997): Workshop: Mujeres, participación política y ciudadanía, San José, Costa Rica, University of Costa Rica.

Marshall, T.H. (1992): Citizenship and social class, in T.H. Marshall and T. Bottomore, Citizenship and Social Class, London, Pluto Press.

Marshall, T.H. and T. Bottomore (1992): Citizenship and Social Class, London, Pluto Press.

McPherson, C.B. (1977): The Life and Times of Liberal Democracy, Oxford, Oxford University Press.

O'Donnell, G. (1993): Estado, democratización y ciudadanía, Nueva sociedad, No. 128, Caracas, Editorial Texto.

Pérez Sáinz, J.P. (1996): De la finca a la maquila, San José, Costa Rica, Latin American Faculty of Social Sciences (FLACSO).

Roberts, B. (ed.) (1998): Ciudadanía y política social, Colección centroamericana de reestructuración, No. 3, San José, Costa Rica, FLACSO.

Shiva, V. (2000): The World on the Edge, in A. Giddens and W. Hutton (eds.), On the Edge: Living with Global Capitalism, London, Jonathan Cape.

Stavenhagen, R. (1998): Consideraciones sobre la pobreza en América Latina, Estudios sociológicos, vol. XVI, No. 46, Mexico City, El Colegio de México.

Tenorio, M. (1995): Estados Unidos: Ciudadanía y cultura en tiempos de desazón. El debate de los noventa, Estudios sociológicos, vol. XIII, No. 39, Mexico City, El Colegio de México.

Touraine, A. (1994): Qu'est-ce que la démocratie?, Paris, Fayard.

Van Steenbergen, B. (1994): Towards a global ecological citizen, in B. van Steenbergen (ed.), The Condition of Citizenship, London, Sage Publications, Ltd.

Wolfe, A. (1977): The Limits of Legitimacy: Political Contradictions of Contemporary Capitalism, New York, Free Press. 